\title{
PENGARUH PENGGUNAAN JENIS GULA TERHADAP MUTU KURMA TOMAT
}

\author{
(The effect of different sugar type on the quality of tomato date)
}

\author{
Amran Laga ${ }^{\left.1^{*}\right)}$, Jumriah Langkong ${ }^{1)}$, dan Muhpidah \\ ${ }^{1 *}$ Program Studi Ilmu dan Teknologi Pangan, Fakultas Pertanian, Universitas Hasanuddin, Makassar, Indonesia \\ *) email Penulis Korespondensi: amranlaga@gmail.com
}

\begin{abstract}
ABSTRAK
Pengolahan tomat segar menjadi suatu produk selain mampu mempertahankan daya simpannya juga mampu meningkatkan nilai jual dari tomat segar. Penggunaan jenis gula yang berbeda pada pengolahan tomat memberikan hasil yang berbeda pula terhadap karakteristik dan penerimaan panelis dari kurma tomat. Hasil analisa kadar air menunjukkan bahwa penggunaan gula pasir memiliki nila kadar air terendah yaitu $13,8 \%$, tingkat keasaman 5,31 dan mampu mempertahankan tingkat vitamin C setelah pengolahan sebesar 60,25\%. Sedangkan penggunaan gula merah pada kurma tomat menghasilkan nilai kadar air sebesar $14,8 \%$, tingkat keasaman 5,84 dan hanya mampu mempertahankan kadar vitamin $\mathrm{C}$ setelah pengolahan sebesar $37,82 \%$. Hasil analisa terhadap tingkat penerimaan dari kurma tomat menunjukkan bahwa kurma tomat dengan penggunaan gula pasir lebih disukai dibandingkan dengan penggunaan gula merah.
\end{abstract}

Kata Kunci : tomat, kurma tomat, gula pasir, gula merah.

\section{ABSTRACT}

The processing of tomatoes into the product was able to maintain the storability and also increased the economic value of fresh tomatoes. Different types of sugar gave different results for the quality and the panelist preference of tomatoe dates. The analysis of water content showed that the use of sugar had the lowest moisture content of $13.8 \%$, acidity level of 5.31 and was able to maintain a level of vitamin $C$ after processing of $60.25 \%$. While the use of brown sugar in tomato dates showed moisture content of $14.8 \%$, acidity level of 5.84 and only able to maintain vitamin $C$ levels after processing of $37.82 \%$. The panelist preference showed that tomato dated with sugar was more preferred than tomato dates with brown sugar.

Keywords : Tomato, tomato dates, sugar, brown sugar .

\section{PENDAHULUAN}

Tomat merupakan salah satu jenis tanaman hortikultura yang banyak dikembangkan khususnya di daerah dataran tinggi. Tomat dalam kalangan rumah tangga dijadikan sebagai salah satu bahan makanan. Selain dari kandungan vitamin C tomat yang tinggi, kadar air yang dimiliki tomat juga cukup tinggi sehingga sangat baik untuk kesehatan terutama kulit. Akan tetapi pemanfaatan tomat saat ini masih terbatas pada pengolahan rumah tangga. Sedikit orang yang mengetahui bahwa tomat dapat dimanfaatkan menjadi produk olahan yang dapat meningkatkan kualitas dan daya simpan tomat. Pemanfaatan tomat menjadi kurma tomat (Kurmato) telah dilakukan sebelumnya. Hasil pengembangan tomat menjadi kurma tomat diketahui masih mampu mempertahankan kadar vitamin C mencapai 60,25\% (Laga, 2018). 
Berdasarkan dari penelitian tersebut sehingga dilakukan pengembangan terhadap proses pembuatan kurma tomat. Pengembangan terhadap produk olahan tomat sebelumnya dilakukan dengan mengolah tomat segar menjadi kurma tomat dengan tambahan gula pasir. Paper ini bertujuan untuk melihat pengaruh penggunaan jenis gula dalam proses pembuatan kurma tomat terhadap karakteristik dari produk akhir yang dihasilkan. Dengan adanya penelitian ini diharapkan dapat menambah wawasan dan minat petani/pelaku usaha terhadap produk olahan buah yang dapat meningkatkan keuntungan serta nilai jual tomat.

\section{METODOLOGI PENELITIAN}

Proses pembuatan kurma tomat dengan penggunaan gula merah sebagai bahan pengganti gula pasir pada proses pembuatan kurma tomat merupakan modifikasi proses pengolahan tomat pada paper sebelumnya. Proses pembuatan kurma tomat disajikan pada Gambar 01.

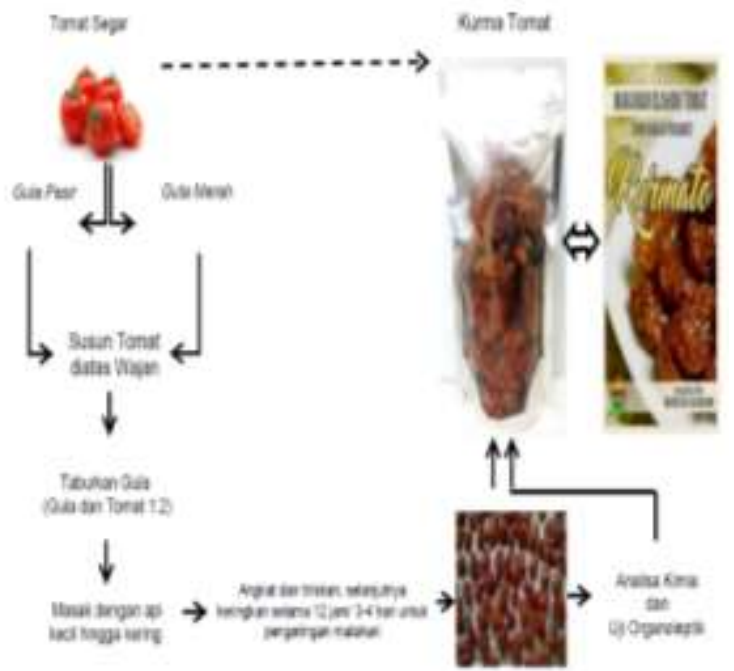

Gambar 01. Proses pengolahan tomat segar menjadi Kurma Tomat (Laga, et.al., 2018)

\subsection{Alat dan Bahan}

Perlatan yang digunakan pada proses pembuatan manisan kurma tomat cukup sederhana. Peralatan yang digunakan yaitu kompor, wajan, sudip kayu, pisau untuk menyayat tomat dan wadah. Bahan yang digunakan dalam pembuatan kurma tomat yaitu buah tomat segar dan gula merah.

\subsection{Pembuatan Kurma Tomat}

Proses pembuatan kurma tomat dimulai dengan proses sortasi dan pengeratan bagian ujung daun buah tomat. Buah tomat kemudian di blanching dengan cara dilakukan perendaman didalam air panas selama 5 menit sampai kulit terluar atau kulit ari tomat mulai terlepas. Setelah itu dilakukan proses pemasakan kurma tomat dengan perbandingan tomat dan gula sebesar 2:1. Tomat dimasak di atas api sedang sampai air dalam bahan mengering dan telah terjadi karamelisasi sempurna. Selanjutnya kurma tomat yang telah dimasak di tiriskan dan dilakukan pengeringan selama 12 jam dengan pengamatan setiap 3 jam.

\subsection{Analisa mutu kurma tomat}

Proses analisa kurma tomat terdiri dari analisa kadar air, $\mathrm{pH}$, total vitamin $\mathrm{C}$ dan uji organoleptik dari kurma tomat menggunakan gula pasir dan kurma tomat yang menggunakan gula merah. Analisa mutu kurma tomat dilakukan di laboratorium analisa pangan Ilmu dan Teknologi Pangan.

\section{HASIL DAN PEMBAHASAN}

Karakteristik kurma tomat yang dihasilkan dari penggunaan dua jenis gula yang berbeda dianalisa dalam beberapa parameter uji yaitu kadar air, total vitamin $\mathrm{C}$, tingkat keasaman $(\mathrm{pH})$ dan seberapa besar penerimaan terhadap kurma tomat yang dihasilkan.

\subsection{Kadar Air}

Kadar air merupakan jumlah air yang terdapat dalam suatu bahan dan dinyatakan dalam persen dari berat bahan. Kadar air merupakan salah satu parameter yang penting dalam pembuatan suatu bahan pangan semi basah seperti kurma tomat. Tomat seperti yang diketahui merupakan salah satu buah dengan kandungan air yang 
relatif tinggi. Kadar air tomat mampu mencapai angka 92,8\% (Wisudawati, 2016). Kadar air yang tinggi dapat menimbulkan pertumbuhan mikroba dan menyebabkan daya simpan tomat rendah, oleh karena itu perlu dilakukan proses pengendalian kadar air sehingga memperpanjang masa simpan tomat. Dengan pengolahan tomat menjadi manisan kurma tomat maka akan menurunkan kadar air yang dimiliki oleh tomat yang disebabkan karena danya proses pengeringan.

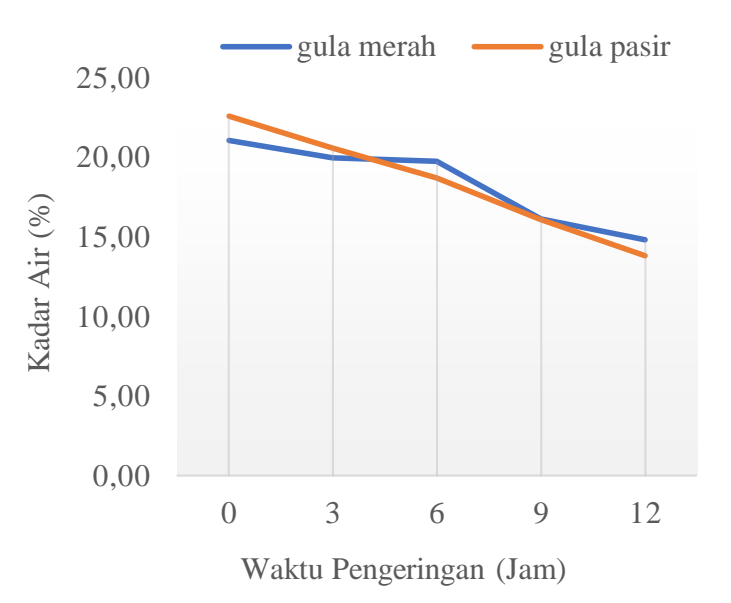

Gambar 02. Pengaruh Waktu Pengeringan terhadap Kadar Air Kurma Tomat

Hasil analisa (Gambar 02) menunjukkan bahwa terjadi penurunan kadar air kurma tomat seiring dengan peningkatan waktu pengeringan. Kadar air tomat utuh mencapai angka $93 \%$ akan tetapi setelah dilakukan proses pengolahn menjadi kurma tomat, terjadi penurunan kadar air yang berkisar antara 13.8\% $14,8 \%$. Berkurang kadar air kurma tomat akan memperpanjang masa simpan kurma tomat. Hal ini disebabkan ketika suatu bahan pangan memiliki kandungan air yang cukup tinggi maka akan sangat mudah untuk rusak terutama akibat adanya kerusakan mikrobiologi. Jumlah kadungan air pada bahan hasil pertanian sangat mempengaruhi daya tahannya terhadap serangan mikroba (Fitriani, 2008), oleh karena itu penting untuk menurunkan kadar air suatu bahan sampai pada kadar tertentu sehingga akan sulit bagi mikroba untuk tumbuh.

Pengamatan pada 12 jam pengeringan menunjukkan bahwa kadar air kurma tomat menurun hingga nilai $13,8 \%$ untuk pemakaian gula pasir dan $14,81 \%$ untuk pemakaian gula merah. Tingakat penurunan kadar air ini cukup signifikan apabila dibandingkan dengan kadar air awal yang mencapai nilai 22,54\%. Kadar air kurma tomat yang dihasilkan cukup baik melihat dari syarat kadar air manisan / buah kering, tidak melebihi batas maksimal kadar air yaitu $31 \%$ untuk buah kering dan $25 \%$ untuk manisan buah.

Kadar air yang dihasilkan menunjukkan bahwa pada 12 jam pengerinagn kadar air penggunaan gula merah lebih tinggi dibandingkan dengan gula pasir. Hal ini dapat disebabkan dari karakteristik gula merah itu sendiri yang memiliki kadar air lebih tinggi sebesar $10,3 \%$ dibandingkan dengan gula pasir yang memiliki kadar air 8,3\% (Imanda, 2017).

\subsection{Vitamin C}

Pengukuran total vitamin $\mathrm{C}$ pada pembuatan manisan kurma tomat perlu dilakukan untuk melihat seberapa besar kandungan vitamin yang terdapatt dalam manisan kurma tomat. Vitamin $\mathrm{C}$ merupakan salah satu vitamin yang hampir terdapat disemua buah-buahan dan sayuran khususnya tomat. Proses pengolahan buah akan mempengaruhi kadar vitamin $\mathrm{C}$ di dalam buah. Proses pengeringan penggunaan panas sangat berpengaruhi terhadap kadar vitamin $\mathrm{C}$ suatu olahan khususnya kurma tomat. 


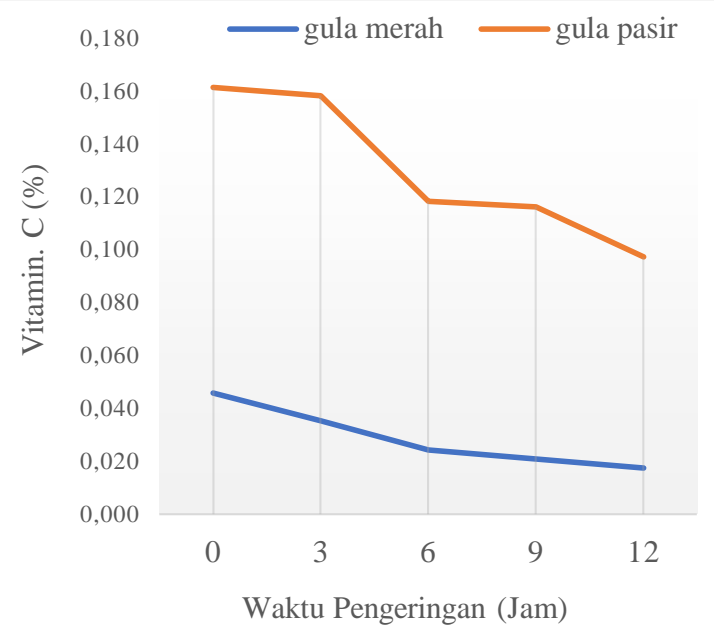

Gambar 03. Pengaruh Waktu Pengeringan terhadap Kadar Vit. C Kurma Tomat

Tomat memiliki kadar vitamin C yang dapat termanfaatkan dalam tubuh, meskipun kadar vitamin $\mathrm{C}$ tomat tidak sebesar kadar vitamin $\mathrm{C}$ dalam jeruk akan tetapi kadar vitamin $\mathrm{C}$ yang terdapat dalam tomat cukup untuk memenuhi asupan yang dibutuhkan oleh tubuh. Pada Gambar 03 terlihat bahwa terjadi penurunan kadar vitamin $\mathrm{C}$ selama proses pengeringan. Persentase vitamin $\mathrm{C}$ yang dihasilkan setelah pengeringan selama 12 jam sebesar $0,1 \%$ untuk penggunaan gula pasir dan 0,01\% (Gambar 03) untuk penggunaan gula merah. Adanya penurunan kadar vitamin $\mathrm{C}$ selama proses pengolahan dikarenakan vitamin $\mathrm{C}$ sangat mudah teroksidasi (Winarno, 2008).

Hasil analisa terhadap vitamin $\mathrm{C}$ juga menunjukkan bahwa penggunaan jenis gula yang berbeda berpengaruh terhadap kadar vitamin $\mathrm{C}$ dari kurma tomat yang dihasilkan. Penggunaan gula pasir mampu untuk mempertahankan kadar vitamin $\mathrm{C}$ hingga $60,25 \%$ dibandingkan penggunaan gula merah sebesar $37,82 \%$. Keadaan ini dipengaruh oleh kemampuan karamelisasi gula pasir dan gula merah yang berbeda. Proses karamelisasi yang terjadi selama pemasakan tomat menggunakan gula pasir lebih baik dibandingkan dengan penggunaan gula merah. Karamel gula yang terbentuk dari gula pasir mampu untuk meresap sempurna kedalam buah tomat sehingga karamel gula menutupi permukaan buah tomat dengan baik. Sedangkan pada penggunaan gula merah, karamel gula yang terbentuk tidak mampu untuk meresap sempurna dan menghasilkan produk olahan yang cukup basah dibandingkan dengan gula pasir. Mukaromah et.al, (2010) menegaskan bahwa vitamin $\mathrm{C}$ dalam bahan dilindungi oleh adanya gula yang digunakan pada proses pengolahan, sehingga kehilangan vitamin $\mathrm{C}$ selama pengolahan berlangsung lambat.

\subsection{Tingkat Keasaman (pH)}

Keasaman dalam suatu bahan pangan dipengaruhi oleh beberapa senyawasenyawa asam yang terdapat dalam bahan pangan khususnya buah. Dalam buah dengan tingkat keasamaan yang tinggi paling sedikit mengandung senyawa yang bersifat asam seperti asam sitrat dan asam askorbat. Selain itu kehadiran senyawa folatil dalam bahan pangan juga mampu untuk mempengaruhi tingkat keasamannya. Keberadaan senyawa asam pada tomat inilah yang menyebabkan perubahan $\mathrm{pH}$ (Buckel, 2007) menjadi pH asam dan mempengaruhi rasa keasaman pada buah tomat.

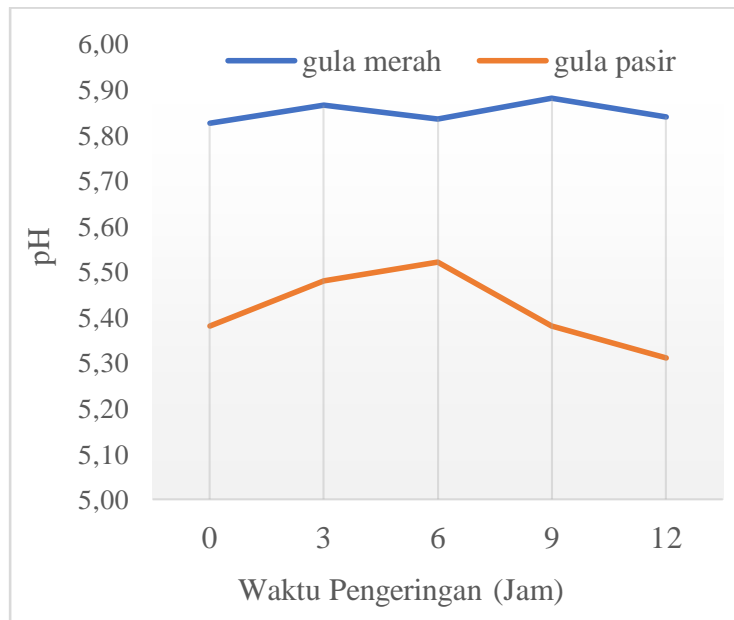

Gambar 04. Pengaruh Waktu Pengeringan terhadap Tingkat Keasaman $(\mathrm{pH})$ Kurma Tomat

Hasil analisa (Gambar menunjukkan bahwa kurma tomat yang dihasilkan memiliki $\mathrm{pH}$ yang berbeda dari 
awal sampai dengan akhir masa pengeringan. Terlihat bahwa terjadi perubahan nilai $\mathrm{pH}$ baik pada penggunaan gula pasir dan gula merah. Akan tetapi adanya perubahan $\mathrm{pH}$ tersebut tidak memberikan hasil yang signiikan berbeda pada waktu pengeringan yang berbeda-beda. Nilai $\mathrm{pH}$ yang dihasilkan berkisar antara 5,31 - 5.88. Nilai $\mathrm{pH}$ yang dihasilkan ini menunjukkan bahwa kondisi produk olahan tomat dalam keadaan asam. Kondisi asam yang dihasilkan erat kaitannya dengan tingkat penurunan vitamin $\mathrm{C}$. Dalam keadaan asam, vitamin $\mathrm{C}$ yang terdapat dalam bahan pangan lebih stabil dibandingkan dalam keadaan basa, dimana vitamin $\mathrm{C}$ menjadi kurang aktif. Oleh karena itu pada penggunaan gula pasir dengan tingkat keasaman 5,31, mampu untuk mempertahan kadar vitamin $\mathrm{C}$ dalam produk sebesar $60,25 \%$.

\subsection{Uji Organoleptik}

Tabel 1. Hasil Pengujian Organoleptik

\begin{tabular}{ccccc}
\hline Jenis & \multicolumn{4}{c}{ Parameter Organoleptik } \\
\cline { 2 - 5 } Gula & Warna & Aroma & Tekstur & Rasa \\
\hline Gula & 3 & 3 & 3.71 & 4.28 \\
Pasir & 3 & & & \\
Gula & 3 & 3 & 2 & 2.14 \\
Merah & 3 & & & \\
\hline
\end{tabular}

Tabel 1 menunjukkan bahwa berdasarkan pengujian organoleptik dari segi warna, kurma tomat dengan penggunaan gula pasir dan penggunaan gula merah sama-sama disukai terlihat dari hasil perhitungan uji organoleptik. Warna pada kurma yang dihasilkan untuk penggunaan gula pasir yaitu coklat kemerahan sementara warna yang dihasilkan pada penggunaan gula merah mendekati warna coklat kehitaman. Perubahan warna tomat yaitu merah menjadi kecoklatan karena adanya proses karamelisasi selama pengolahan kurma tomat. Pada saat pemasakan kurma tomat, gula yang ditambahkan akan menjadi karamel (pencoklatan non enzimatis). Hal inilah yang menyebabkan warna asli pada buah-buahan setelah dimasak mengalami perubahan warna. Ketika proses karamelisasi, terjadi degradasi gula tanpa asam amino akibat dari pemanasan gula diatas titik cairnya (Desrosier, 2008).

Parameter lain dari uji organoleptik yaitu rasa. Rasa pada kurma tomat yang dihasilkan, menurut uji orgaleptik disukai oleh panelis. Rasa dalam kurma tomat dihasilkan dari proses karamelisasi selama pemasakan. Pemasakan dilakukan dengan penambahan gula pasir dan gula merah yang dimasak pada api sedang. Gula akan memberikan rasa manis pada tomat sehingga kurma tomat yang dihasilkan lebih disukai. Fitriyono (2010) menyatakan bahwa gula yang dipanaskan terus hingga suhunya melampaui titik leburnya akan terjadi proses karamelisasi. Pembentukan karamel ini dapat meningkatkan citarasa dan warna pada makanan.

Kurma tomat dengan penggunaan gula pasir rasanya lebih disukai dibandingkan dengan penggunaan gula merah. Kurma tomat dengan gula merah lebih manis dibandingkan dengan gula pasir. Adanya perbedaan penerimaan rasa pada kurma tomat dapat disebabkan oleh pengaruh penggunaan jenis gula. Gula pasir mengandung sukrosa yang memberikan keseimbangan rasa yang lebih baik pada keadaan asam. Sedangkan pada penggunaan gula merah, rasa yang dihasilkan lebih manis. Hal ini dikarenakan tingkat kemanisan gula merah yang lebih tinggi dibandingkan dari gula pasir. Tingkat kemanisan tersebut dipengaruhi oleh kandungan sukrosa dan gula invert yang terdapat dalam gula merah (Razak et al., 2012).

Hasil uji organoleptik menunjukkan bahwa tekstur kurma tomat dengan penggunaan gula pasir lebih disukai dibandingkan dengan penggunaan gula merah. Tekstur kurma tomat dipengaruhi oleh adanya proses karamelisasi. Tekstur kurma tomat juga dipengaruhi oleh senyawa kimia yang terdapat pada masing- 
masing jenis gula. Gula merah memiliki kandungan gula invert yang mana sangat berpengaruh terhadap tekstur (hardness). Tabitha et al. (2017) mengemukakan bahwa peningkatan penggunaan gula aren menyebabkan semakin tinggi nilai hardness. Peningkatan nilai ini dipengaruhi oleh kederadaan gula invert pada gula merah.

Kurma tomat dengan penggunaan gula pasir lebih mudah dibentuk pada saat proses pemasakan selesai. Pembentukan kurma tomat dimaksudkan untuk memberikan penampakan yang lebih baik dari produk. Gula pasir meresap masuk ke dalam tomat dan membentuk suatu tekstur produk yang lunak. Sehingga selama proses pengeringan sesekali kurma tomat dengan penggunaan gula pasir masih bias untuk di sesuaikan bentuk dan ukutan produk akhirnya. Sementara kurma tomat dengan penggunaan gula merah sulit untuk disesuaikan bentuk dan ukuran produk akhir yang dihasilkan. Hal ini disebabkan karena, setelah proses pemasakan berakhir, produk kurma yang dihasilkan mengeras dengan cepat. Tekstur pada kurma tomat dengan penggunaan gu;a pasir lebih mudah di cerna, sedangkan pada gula merah hamper menyerupai case hardening. Dimana pada bagian luar kurma mengeras akan tetapi pada bagian dalam masih basah dan tidak kering. Produk yang mengandung gula invert akan menghasilkan tekstur yang lebih padat (Figoni, 2008).

Aroma tomat kurma yang dihasilkan disukai oleh panelis. Aroma yang dihasilkan berasal dari aroma tomat dan karamel gula yang selama pemasakan menghasilkan aroma kurma tomat yang disukai oleh panelis. Proses karamelisasi selain menghasilkan warna dan tekstur yang baik juga mempengaruhi aroma yang dihasilkan. Kurma tomat yang dihasilkan memiliki aroma yang baik, dimana aroma tomat sudah tidak terlalu jelas karena tergantikan oleh aroma karamel gula. Sehingga ketika dilakukan pengujian, aroma kurma tomat disukai oleh panelis. Gula memiliki aroma yang khas karena adanya kandungan asam-asam organik.
Selain itu gula juga memiliki aroma khas karamel. Aroma khas karamel tersebut disebabkan karena adanya reaksi karamelisasi akibat panas selama pemasakan

(Sutrisno et al. 2014).

\section{KESIMPULAN}

Berdasarkan hasil analisa dari kurma tomat yang dihasilkan maka disimpulkan bahwa penambahan gula pasir pada tomat lebih baik dibandingkan dengan penambahan gula merah selama proses pengolahan tomat menjadi kurma tomat. Hal ini terlihat dari hasil analisa terhadap kadar air yaitu dengan nilai $13,8 \%$, analisa vitamin C dengan nilai $0.097 \%$ serta nilai pH yang yang berkisar pada nilai 5.31. Sementara hasil uji organoleptik menunjukkan bahwa kurma tomat dengan perlakuan penambahan gula pasir lebih disukai dibandingkan dengan penambahan gula merah dari segi rasa dan tekstur.

\section{DAFTAR PUSTAKA}

Buckle, K.A., Edward, R. A., Fleet, G.H., \& Wootto, W. (2007). Ilmu Pangan. Penerjemah H. Purnomo dan Adiono. Jakarta : Universitas Indonesia.

DSN-SNI No. 1718. (1996). Syarat Mutu Manisan. Badan Standarisasi Nasional.

Desrosier, N.W. (2008). Teknologi Pengawetan Pangan. Terjemahan $\mathrm{M}$. Muljohardjo. Jakarta : Universitas Indonesia.

Figoni, P. (2008). How Baking Works : Exploring the fundamental of baking science 2nd Ed. New Jersey: John Wiley \& Sons, Inc.

Fitriani, S. (2008). Pengaruh Suhu dan Lama Pengeringan Terhadap Beberapa Mutu Manisan Belimbing Wuluh (Averrhoa bilimbi L.) Kering. Jurnal SAGU, 7 (1) : 32-37.

Fitriyono. 2010. Ilmu Pengetahuan Bahan Pangan. Bandung: Alfabeta.

Imanda, M.R., (2007). Kajian Pengaruh Suhu dan Waktu Penyimpanan Terhadap Karakteristik Mutu Produk 
Sirup Gula Invert dari Gula. Skripsi. Institut Pertanian Bogor.

Laga A., Langkong J., Muhpidah, Fitri, \& Wakiah, N. (2018). Pengembangan Olahan Tomat Enrekang dalam Bentuk Kurma Tomat (Karakteristik Kurma Tomat). Jurnal Dinamika Pengabdian, $4(\mathrm{~K}): 72-78$.

Mukaromah, U., Susetryorini, S. H., \& Aminah, S. (2010). Kadar Vitamin C, Mutu Fisik, Ph dan Mutu Organoleptik Sirup Rosella (Hibiscus sabdariffa, L) berdasarkan Cara Ekstraksi. Jurnal Pangan dan Gizi, 1(1): 43-51.

Razak, A.R., Sumarni, N. K., \& Rahmat, B. (20120. Optimalisasi Hidrolisis Sukrosa Menggunakan Resin Penukar KationTipe Sulfonat. Jurnal Natural Science, 1(1): 119-131.

SNI 01-3710-1995 Syarat Mutu Buah Kering. Badan Standarisasi Nasional.

Sutrisno, C.D.N., \& Susanto, H. D. (2014). The Influence of Type and Concentration Paste (Coconut Milk and Nuts) Toward Brown Sugar Quality Product. Jurnal Pangan dan Agroindustri, 2(1) : 97-105.

Tabitha, C. E., Thomas, I. P. S., \& Erni, S. (2017). Effect of Sugar and Palm Sugar Proportion on the Characteristics Cream cheese Cake After One Week Frozen Storage. Jurnal Teknologi Pangan dan Gizi, 16 (2): 88-95.

Winarno, F. G. 2008. Kimia Pangan dan Gizi. Jakarta : Gramedia Pustaka Utama.

Wisudawati, P. (2016). Aplikasi Minyak Kayu Manis Sebagai Antimikroba Pada Edible Coating Manisan Tomat Cherry. Thesis. Institut Pertanian Bogor. 